\title{
SMAR WELCO SEBAGAI SOLUSI PENINGKATKAN PRODUKTIVITAS DAN PENGHEMATAN ENERGI LISTRIK BUDIDAYA PERIKANAN
}

\author{
Bagas Woro Saputra ${ }^{1}$, Annisa Nofita Wulandari ${ }^{2}$, Istiqomah Ayu Mustika ${ }^{3}$, Muhamad Ridwan \\ Sya'bani $^{4}$, Aqid Dwi Darmawan ${ }^{5}$ \\ ${ }^{1,2}$ Jurusan Pendidikan Teknik Elektro, Fakultas Teknik, Universitas Negeri Yogyakarta \\ email : bagas.woro2016@student.uny.ac.id
}

\begin{abstract}
Design of Smar Welco aims to optimize perrot fish cultivation profit by reducing the cost of electrical energy and replace the waterwheel's control system from manual to automatic in order to facilitate and reduce the cost of its treatment. Smar Welco work by using the Arduino as a main controller and fuzzy logic as a main system and solar cell as the main power supplay. Temperature sensor (DS18B20) and solar light sensor (LDR) is used as the input where the value of both of these sensors will be sent to the Arduino to determine the speed of the waterwheel based on fuzzy logic. This tool is also equipped with automatic ph sensor and wavecom module to send a notification in the form of short message service (sms) to farmers when the ph levels in the embankment are not standard. A method of designing Smar Welco use approach of waterfal method. The result of the application of Smar Welco in embankment at our partner is obtained that the cost of electrical energy to operate waterwheel down up to $\mathrm{Rp} 3.126 .400,00$ in one time harvrest.
\end{abstract}

Keywords: waterwheel, fuzzy logic, arduino

\begin{abstract}
ABSTRAK
Yogyakarta memasok ikan dari daerah lain karena produksi dalam provinsi belum mencukupi untuk memenuhi permintaan pasar. Salah satu penyebabnya adalah belum optimalnya produktivitas hasil ikan produsen perikanan di Yogyakarta. Pembuatan Smar Welco bertujuan untuk mengoptimalkan produktivitas dan profit budidaya perikanan dengan menurukan jumlah ikan mati sebelum dipanen karena kekurangan oksigen dan menekan biaya energy listrik. Metode yang digunakan adalah penelitian pengembangan dengan pendekatan water fall. Cara kerja Smar Welco menggunakan Arduino dan logika fuzzy sebagai system utamanya serta solar cell sebagai power suplay nya. Sensor suhu, sensor cahaya, dan $\mathrm{pH}$ meter digunakan sebagai inputan dimana angka dari ketiga sensor tersebut dikirim ke Arduino untuk menentukan kecepatan kincir air berdasarkan logika fuzzy. Putaran kincir air akan menghasilakan kadar oksigen yang sesuai dengan kebutuhan ikan. Metode penerapan Smar Welco menggunakan pendekatan water fall dari analisi kebutuhan hingga pemantauan hasil. Penerapan Smar Welco telah berhasil meningktkn produktivitas hasil ikan sebesar 8,3\% dan menurunkan jumlah ikan yang mati sebesar $76 \%$ serta menurunkan biaya listrik hingga 46,16 \% atau sekitar Rp 3.119.935,00 untuk satu kali masa panen.
\end{abstract}

Kata kunci : kincir air, logika fuzzy, arduino

\section{PENDAHULUAN}

Dengan luas wilayah lautan lebih dari 5,8 juta $\mathrm{km}^{2}$ membuat Indonesia memilki sumber daya alam khususnya perikanan yang sangat melimpah dan sangat berpotensi untuk dikembangkan. Salah satunya adalah budidaya ikan nila yang menjanjikan profit melimpah jika dikelola dengan benar. Berdasarkan data dari Kementrian Kelautan dan Perikanan menyatakan konsumsi ikan nila secara umum terus meningkat dan Provinsi dengan pertumbuhan tertinggi adalah Daerah Istimewa Yogyakarta yaitu sebesar $30.98 \%$ pada tahun 2017. Permintaan pasar domestik maupun dari 
manca negara cenderung mengalami peningkatan, sehingga usaha budidaya ikan nila memiliki prospek yang cerah untuk dijadikan bisnis yang menguntungkan.

Salah satu sentra penghasil ikan nila di Yogyakarta adalah UPT Pengembangan Budidaya Dan Pemasaran Perikanan Kabupaten Sleman yang dikepalai oleh Ir Hari Sukartono. Meskipun sudah mengoptimalkan jumlah kolam dan waktu produksi, tetapi jumlah ikan nila yang dihasilakan UPT ini masih belum dapat memenuhi kebutuhan ikan nila Kabupaten Sleman dan Provinsi D.I. Yogyakarta (Ir. Hari,2018). Permasalahan utama yang dihadapi oleh UPT Pengembangan Budiaya dan Pemasaran Perikanan Kabupaten Sleman adalah dalam pengontrolan kadar oksigen air tambak. Hal ini menyebabkan waktu panen yang lebih lama dan banyak ikan yang mati (50 - 80 ekor dalam satu kali masa panen) sebelum panen karena kekurangan suplay oksigen. UPT hanya menggunakan 1 kincir air untuk mensuplai oksigen pada tambak sehingga belum mencukupi kadar oksigen yang dibutuhkan tambak karena keterbatasan daya listrik yang terpasang. Kincir air dioperasikan selama 24 jam dengan kecepatan tinggi untuk menghindari gagal panen sehingga biaya listrik untuk kincir air sangat tinggi ( Rp 520.000,00 per minggu) . Meskipun demikian kadar oksigen yang dihasilkan hanya 2 - 3 ppm padahal standart kadar oksigen untuk ikan nila agar dapat berkembang secara maksimal adalah 5-7 ppm (Effendi 2003: 26).

Pengolahan air tambak merupakan bagian dari ilmu akuakultur diantaranya yang dilakukan Fowler, dkk yaitu membuat sistem kontrol untuk sistem akuakultur intensif resirkulasi dengan menggunakan mikrokontroler. Algoritma yang digunakan adalah logika fuzzy (Fowler, 1994). Selain itu, Indriawati (2008) pada penelitiannya membuat modul kontrol kualitas air tambak udang sebagai sarana pembelajaran teknik budidaya udang. Namun sistem kontrol ini mempunyai kekurangan yaitu pengoperasiannya masih menggunakan kontrol on/off dan secara manual.

Oleh karenanya, solusi untuk meningkatkan produktivitas hasil ikan dan mengurangi biaya energy listrik budidaya perikanan yaitu dengan Smar Welco (Smart Water Wheel Speed Controller) yang merupakan inovasi teknologi kincir air listrik otomatis menggunakan sistem logika fuzzy dengan sensor cahaya sinar matahari dan sensor suhu sebagai pengontrolnya serta dilengakapi dengan alat pengontrol $\mathrm{pH}$ otomatis dan menggunakan sollar cell sebagai suplai dayanya. Sensor sinar matahari (LDR), sensor suhu san sensor ph digunakan karena berpengaruh terhadap suplay oksigen pada tambak (Effendi 2003: 26).

Keuntungan dari SMAR WELCO ini adalah pemutaran kincir air yang otomatis, memudahkan pembudidaya dalam menyuplai kadar oksigen pada tambak untuk mengoptimalkan hasil budidaya ikan dengan mengurangi jumlah ikan yang mati sebelum dipanen. Selain itu, dengan adanya sistem kontrol ini akan memperkecil energi listrik yang dibutuhkan dan meningkatkan produktivitas hasil ikan nila, serta mengurangi biaya perawatan kincir air. Tujuan dari diterapkanya alat ini adalah untuk mengoptimalkan produktivitas hasil ikan dan profit budidaya perikanan.

Diharapkan setelah alat ini dipatenkan maka dapat membantu seluruh jenis budidaya perikanan yang masih menggunakan kincir air manual serta mensukseskan progam hemat energy dan penggunaan energy terbarukan yang terus digaungkan oleh pemerintah pusat.

\section{METODE}

Metode pengembangan yang digunakan dalam penerapan teknologi SMAR WELCO ini menggunakan model pendekatan water fall yang dikembangkan Davis, Bershoff, dan Comer, (1988:1453); Pressman （2015:41- 
42).Langkah-langkah metodenya adalah sebagai berikut:

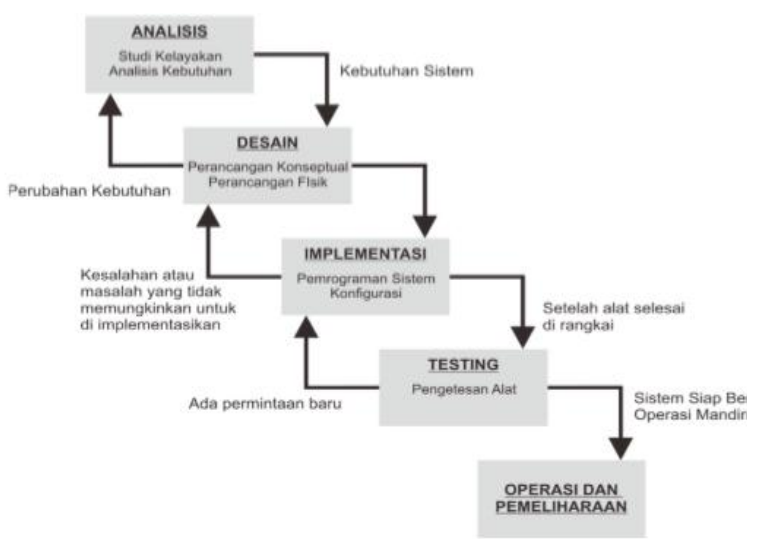

Gambar 1. Metode Pengembangan

Pada tahap analisis kebutuhan dilakukan observasi dan wawancara kepada Ir. Hari Sukartono selaku kepala UPT Pengembangan Budidaya Dan Pemasaran Perikanan Kabupaten Sleman mengenai produksi dan kendala yang dialami UPT. Tahap selanjutnya adalah membuat rancangan desain Smar Welco dan pengumpulan dasar teori dari masing-masing komponen pembentuk alat menjadi bagian utama dan pertama dari rencana pembuatan alat.

Komponen yang dibutuhkan diantaranya sensor LDR (cahaya matahari), Sensor DS18B20 (suhu tambak),Mikrokontroller (Arduino Mega), dan solar cells. Langkah berikutnya adalah membuat diagram blok smar welco untuk mengetahui sistem cara kerja alat dan membuat desain alat yang akan diterapkan.

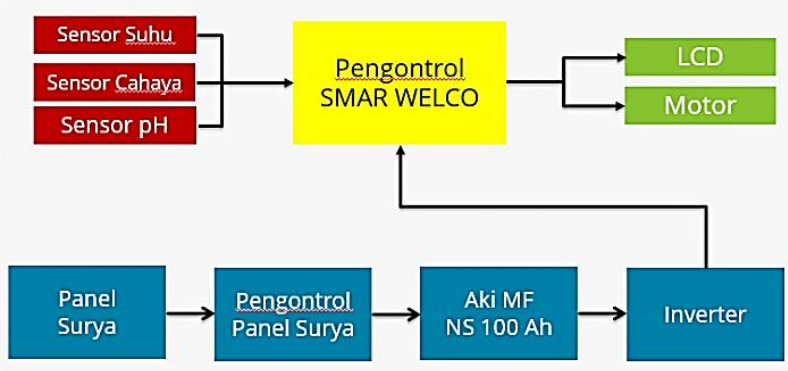

Gambar.2 Diagram Blok Smar Welco

Catu daya untuk SMAR WELCO menggunakan Solar Cell 100 WP yang dikontrol oleh Controller Solar Cell type 40 A $12 \mathrm{~V} / 24 \mathrm{~V}$ dengan arus sementara disimpan oleh Aki MF NS 100 Ah. Keluaran dari Aki MF NS 100 Ah bertegangan $24 \mathrm{~V}$ diubah oleh Inverter $1500 \mathrm{~W}$ menjadi tegangan kerja $220 \mathrm{~V}$. Output dari inverter digunakan untuk power suplay controller SMAR WELCO. Controller SMAR WELCO menggunakan Arduino Mega sebagai main controller dengan inputan sensor suhu DS18B20, sensor cahaya LDR, dan sensor ph. Controller akan mengeluarkan arus listrik sesuai inputan dari ketiga sensor tersebut untuk menentukan berapa kecepatan untuk Motor kincir air. Spesifikasi motor kincir air berdaya 1 HP (746 W) 220 V 1440 rpm.

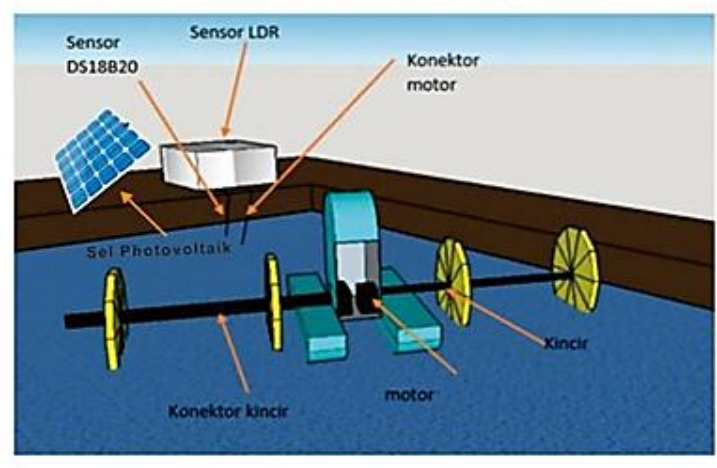

Gambar 3. Desain Smar Welco

Desain Penerapan Alat SMAR WELCO pada kolam 005 UPT Pengembangan Budidaya dan Pemasaran Periknan Kabupaten Sleman dengan luas kolam $960 \mathrm{~m}^{2}$

\section{Fuzzyfikasi}

Merupakan penjabaran lebih rinci dari cara kerja Smar Welco

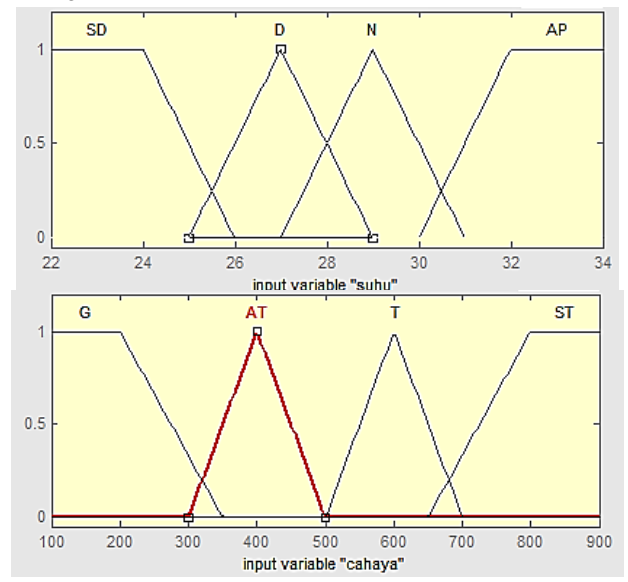

Gambar 3. Fungsi Keanggotaan Fuzzy untuk Input Kontrol Kecepatan Motor 


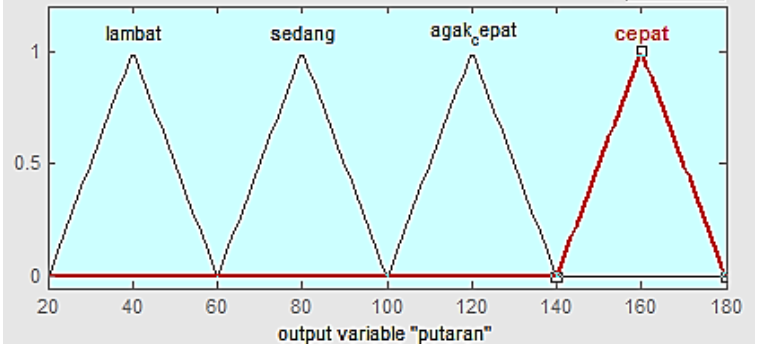

Gambar 4. Fungsi Keanggotaan Fuzzy untuk

Output Kontrol Kecepatan Motor

Kemudian dari fungsi keanggotaan tersebut maka dapat dibuat aturan if then rule sebagai berikut:

1. If suhu is Dingin and cahaya is Gelap then putaran is cepat

2. If suhu is Normal and cahaya is Terang then putaran is agak_cepat

3. If suhu is Normal and cahaya is Agak Terang then putaran is sedang

4. If suhu is Hangat and cahaya is Terang then putaran is sedang

5. If suhu is Hangat and cahaya is Sangat

Terang then putaran is lambat

Sebelum diterapkan SMAR WELCO telah dikalibrasikan dan dikonfigurasi dengan kondisi riil pada tambak.

Tabel 1. Hasil Konfigurasi SMAR WELCO

\begin{tabular}{|l|c|c|c|}
\hline \multicolumn{1}{|c|}{ Suhu } & $\begin{array}{c}\text { Cahaya } \\
\text { Matahari }\end{array}$ & pH & $\begin{array}{c}\text { Kecepatan } \\
\text { Motor }\end{array}$ \\
\hline $\begin{array}{l}\text { Air } \\
\text { Dingin } \\
\left(20^{\circ} \mathrm{C}\right)\end{array}$ & Tidak Ada & $<5$ & $900 \mathrm{rpm}$ \\
\hline $\begin{array}{l}\text { Air Biasa } \\
\left(25^{\circ} \mathrm{C}\right)\end{array}$ & Ada & $5-9$ & $450 \mathrm{rpm}$ \\
\hline $\begin{array}{l}\text { Air } \\
\text { Hangat } \\
\left(34^{\circ} \mathrm{C}\right)\end{array}$ & Ada & $>9$ & $\sim 0 \mathrm{rpm}$ \\
\hline
\end{tabular}

Pada tahap implementasi meliputi perancangan dan pembuatan SMAR WELCO. Penerapan Alat telah diterapkan pada tambak mitra seluas $960 \mathrm{~m}^{2}$ selama 2 bulan. Berikut adalah gambar dari penerapan SMAR WELCO pada tambak.

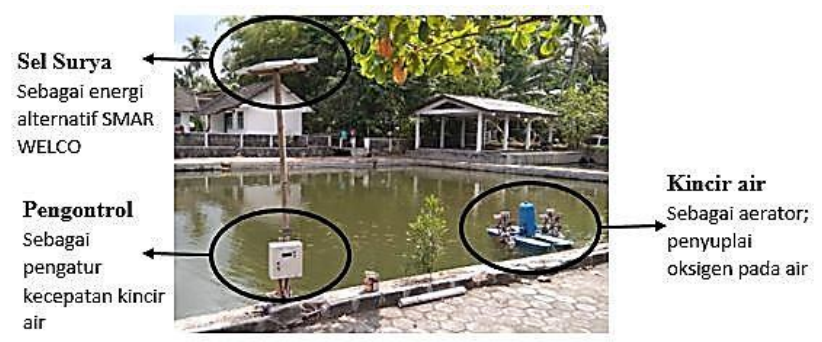

Gambar 5. Penerapan Smar Welco

Kondisi sekarang ditambak dipasang 2 kincir air $1 \mathrm{HP}$ dan motor $500 \mathrm{~W}$ dimana keduanya telah dikontrol oleh SMAR WELCO dan menggunakan daya dari Solar Cell untuk jam $\quad 10.00$ sampai 17.00 dan sisanya menggunakan daya PLN.

\section{Pengontrolan dan Pemantauan Hasil}

Setelah diterapkannya SMAR WELCO dilakukan pengontrolan alat disetiap minggunya. Pengontrolan dilakukan oleh anak tambak yang berjaga selama 24 jam dengan mengontrol jumlah ikan yang mati dan pembelian token listrik PLN selama kurang lebih dua bulan. Tujuan dari pengontrolan alat ini adalah untuk mengetahui kebermanfaatan alat sekaligus mengambil data selama kurang lebih dua bulan disetiap minggunya. Dengan begitu, pemantauan hasil produksi ikan dapat diketahui dengan membandingkan jumlah ikan yang mati dan pembelian token listrik PLN sebelum dan sesudah penerapan alat. 
Tabel 2. Hasil Pemantauan Kinerja SMAR WELCO

\begin{tabular}{|c|c|c|c|l|c|c|}
\hline $\begin{array}{c}\text { Minggu } \\
\text { ke- }\end{array}$ & $\begin{array}{c}\text { Tanggal } \\
\text { Pengecekan }\end{array}$ & $\begin{array}{c}\text { Ikan Nila } \\
\text { Mati } \\
\text { (ekor) }\end{array}$ & $\begin{array}{c}\text { Ikan } \\
\text { Nila } \\
\text { Hidup } \\
\text { (ekor) }\end{array}$ & Keadaan & $\begin{array}{c}\text { Suhu } \\
\text { Kolam }\end{array}$ & $\begin{array}{c}\text { Kadar } \\
\text { oksigen } \\
\text { terlarut }\end{array}$ \\
\hline 1 & $26 / 4 / 18$ & 3 & 2197 & $\begin{array}{l}\text { Malam } \\
\text { Hari }\end{array}$ & $\begin{array}{c}20-21^{0} \\
\mathrm{C}\end{array}$ & $5 \mathrm{ppm}$ \\
\hline 2 & $3 / 5 / 18$ & 1 & 2196 & $\begin{array}{l}\text { Siang } \\
\text { Hari }\end{array}$ & $\begin{array}{c}27-28^{0} \\
\mathrm{C}\end{array}$ & $6 \mathrm{ppm}$ \\
\hline 3 & $9 / 5 / 18$ & 2 & 2194 & $\begin{array}{l}\text { Siang } \\
\text { Hari }\end{array}$ & $\begin{array}{c}29-30^{0} \\
\mathrm{C}\end{array}$ & $6 \mathrm{ppm}$ \\
\hline 4 & $20 / 5 / 18$ & 2 & 2192 & $\begin{array}{l}\text { Malam } \\
\text { Hari }\end{array}$ & $\begin{array}{c}23-25^{0} \\
\mathrm{C}\end{array}$ & $5 \mathrm{ppm}$ \\
\hline 5 & $28 / 5 / 18$ & 3 & 2189 & $\begin{array}{l}\text { Malam } \\
\text { Hari }\end{array}$ & $\begin{array}{c}19-21^{0} \\
\mathrm{C}\end{array}$ & $3 \mathrm{ppm}$ \\
\hline 6 & $4 / 6 / 18$ & 1 & 2188 & $\begin{array}{l}\text { Siang } \\
\text { Hari }\end{array}$ & $\begin{array}{c}25-28^{0} \\
\mathrm{C}\end{array}$ & $6 \mathrm{ppm}$ \\
\hline 7 & $27 / 6 / 18$ & 4 & 2184 & $\begin{array}{l}\text { Malam } \\
\text { Hari }\end{array}$ & $\begin{array}{c}18-21^{0} \\
\mathrm{C}\end{array}$ & $3 \mathrm{ppm}$ \\
\hline 8 & $4 / 7 / 18$ & 2 & 2182 & $\begin{array}{l}\text { Siang } \\
\text { Hari }\end{array}$ & $\begin{array}{c}26-28^{0} \\
\mathrm{C}\end{array}$ & $5 \mathrm{ppm}$ \\
\hline
\end{tabular}

\section{HASIL DAN PEMBAHASAN}

Alat Pengendali kecepatan motor kincir air secara otomatis yaitu SMAR WELCO yang telah melalui tahap uji coba dan penerapan di kolam mitra selama 8 minggu dengan hasil menyelesaikan permasalahan pada mitra yaitu telah menurunkan jumlah ikan yang mati sebesar $\frac{75-18}{75} \times 100 \%=76 \%$ dan telah menurunkan biaya penggunaan listrik mitra sebesar $\frac{R p 74.285,00-R p 40.000,00}{R p 74.285,00} \times 100 \%=$ 46,15 \% atau Rp 3.119.935,00 untuk satu kali masa panen atau $\mathrm{Rp} 12.479 .740,00$ untuk satu siklus masa panen dalam satu tahun.

Tabel 3. Perbandingan Sebelum dan Sesudah Penerapan SMAR WELCO

\begin{tabular}{|c|c|c|c|c|}
\hline $\begin{array}{c}\text { Kondisi } \\
\text { Tambak }\end{array}$ & $\begin{array}{c}\text { Jumlah } \\
\text { Ikan } \\
\text { Mati }\end{array}$ & $\begin{array}{c}\text { Jumlah } \\
\text { Ikan } \\
\text { Hidup }\end{array}$ & Berat ikan & Biaya Listrik \\
\hline $\begin{array}{c}\text { Sebelum } \\
\text { Penerapan }\end{array}$ & 75 Ekor & $\begin{array}{c}2135 \\
\text { Ekor }\end{array}$ & $\begin{array}{c} \pm 300 \\
\text { gram/ ekor }\end{array}$ & $\begin{array}{l}\text { Rp } 520.000,00 / 7 \text { hari } \\
(\operatorname{Rp} 74.285,00 / \text { hari })\end{array}$ \\
\hline $\begin{array}{c}\text { Setelah } \\
\text { Penerapan }\end{array}$ & 18 Ekor & $\begin{array}{c}2182 \\
\text { Ekor }\end{array}$ & $\begin{array}{c} \pm 320 \\
\text { gram/ekor }\end{array}$ & $\begin{array}{l}\text { Rp } 520.000,00 / 13 \text { hari } \\
(\operatorname{Rp} 40.000,00 / \text { hari })\end{array}$ \\
\hline Selisih & 47 Ekor & 47 Ekor & $\begin{array}{c} \pm 20 \\
\text { gram/ekor }\end{array}$ & Rp 34.285,00/hari \\
\hline
\end{tabular}

SMAR WELCO juga berhasil meningkatkan produktivitas sesuai table berikut

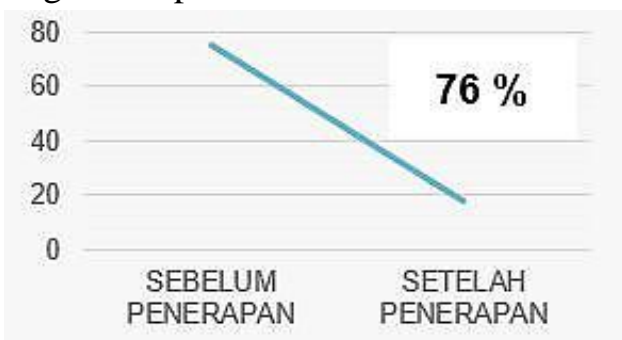

\section{Produktivitas}

\begin{tabular}{ll}
\hline Sebelum & Sesudah \\
$\frac{6 \text { kuintal }}{2,5 \text { kuintal }}=2,4$ & $\frac{6,5 \text { kuintal }}{2,5 \text { kuintal }}=2,6$
\end{tabular}

Gambar 6a. Grafik penurunan jumlah ikan yang mati 


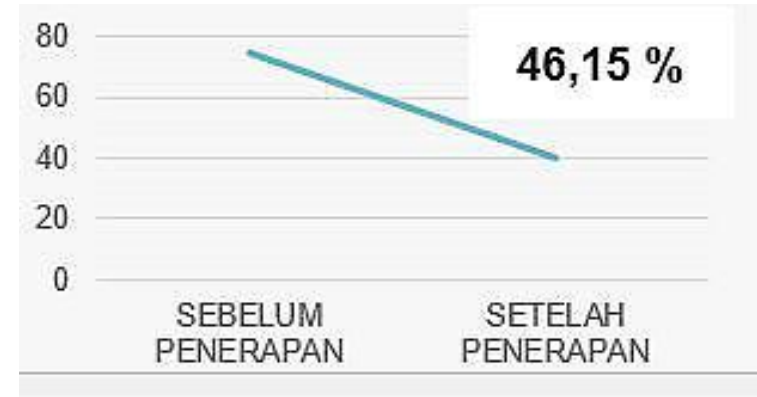

Gambar 6b. Grafik penghematan energi listrik

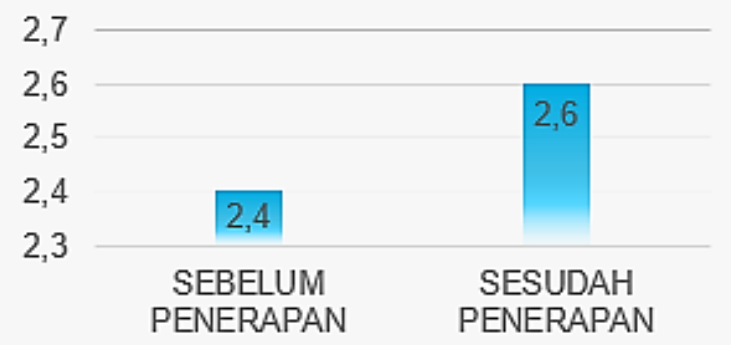

Gambar 6c. Grafik peningkatan produktivitas

\section{SIMPULAN}

SMAR WELCO merupakan pengontrol kecepatan kincir otomatis dengan inputan berupa sensor cahaya, sensor suhu, dan sensor ph dengan menggunakn arduino mega dan logika fuzzy sebagai main sistemnya dan solar cell sebagai sumber dayanya yang memudahkan pembudidaya dalam menyuplai oksigen pada tambak, meningkatkan produktivitas dan profit budidaya perikanan dan memperkecil penggunaaan energi listrik yang digunakan.

Setelah Smar Welco dipatenkan, diharapkan alat ini akan membantu seluruh petambak untuk mengurangi biaya pemakaian energi listrik sehingga profit petambak tidak menurun kaikndaltamifsathargarilistrik yang terus naik.

\section{DAFTAR RUJUKAN}

Davis, Alan N. Bershoff, Edward H. \& Comer, Edward R. 1988. A Strategy for comparing alternative software development life cycle models. IEEE Transactions on Software Engineering, Vol. 14, No. 10, October 1988. Page(s): $1453-1461$

Effendi, Hefni. 2003. Telaah Kualitas Air-Bag iPengelola Sumber Daya dan Lingkungan Perairan. Yogyakarta: Kanisius.

Fowler, dkk. 1994. Microcontrollers in Recirculating Aquaculture Systems. Florida Cooperative Extension Service, Institute of Food and Agricultural Sciences. University of Florida.

Pressman, Roger S. \& Maxim, Bruce R. 2015. Software Engineering, A practitionare's approach, 8th edition. New York: Mc Graw-Hill Education

Pusat Data Statistik Kementrian Kelautan dan Perikanan. 2016. Informasi Kelautan dan Perikanan . Diakses dari laman www.statistik.kkp.go.id. Diakses tanggal 01 April 2018 